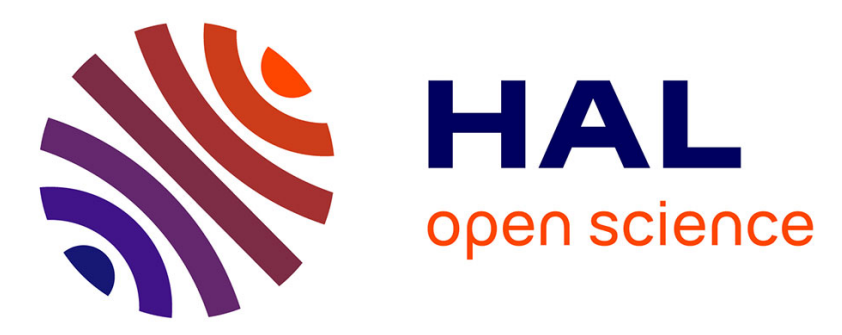

\title{
An analysis of pavement heat flux to optimize the water efficiency of a pavement-watering method
}

\author{
Martin Hendel, Morgane Colombert, Youssef Diab, Laurent Royon
}

\section{To cite this version:}

Martin Hendel, Morgane Colombert, Youssef Diab, Laurent Royon. An analysis of pavement heat flux to optimize the water efficiency of a pavement-watering method. Applied Thermal Engineering, 2015, 78 (5), pp.658-669. 10.1016/j.applthermaleng.2014.11.060 . hal-01698350v5

\section{HAL Id: hal-01698350 \\ https://hal.science/hal-01698350v5}

Submitted on 20 Apr 2023

HAL is a multi-disciplinary open access archive for the deposit and dissemination of scientific research documents, whether they are published or not. The documents may come from teaching and research institutions in France or abroad, or from public or private research centers.
L'archive ouverte pluridisciplinaire HAL, est destinée au dépôt et à la diffusion de documents scientifiques de niveau recherche, publiés ou non, émanant des établissements d'enseignement et de recherche français ou étrangers, des laboratoires publics ou privés. 


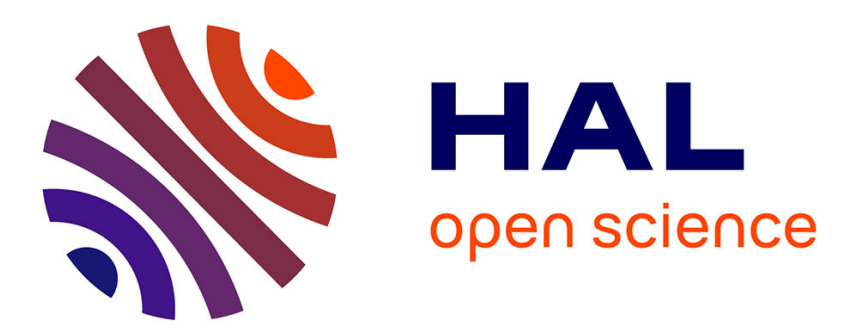

\title{
An analysis of pavement heat flux to optimize the water efficiency of a pavement-watering method
}

\author{
Martin Hendel, Morgane Colombert, Youssef Diab, Laurent Royon
}

\section{To cite this version:}

Martin Hendel, Morgane Colombert, Youssef Diab, Laurent Royon. An analysis of pavement heat flux to optimize the water efficiency of a pavement-watering method. 2015. hal-00991145v4

\section{HAL Id: hal-00991145 \\ https://hal.science/hal-00991145v4}

Preprint submitted on 21 May 2015

HAL is a multi-disciplinary open access archive for the deposit and dissemination of scientific research documents, whether they are published or not. The documents may come from teaching and research institutions in France or abroad, or from public or private research centers.
L'archive ouverte pluridisciplinaire HAL, est destinée au dépôt et à la diffusion de documents scientifiques de niveau recherche, publiés ou non, émanant des établissements d'enseignement et de recherche français ou étrangers, des laboratoires publics ou privés. 


\title{
An analysis of pavement heat flux to optimize the water efficiency of a pavement-watering method
}

\author{
Martin HENDEL ${ }^{1,2,3 *}$, Morgane COLOMBERT ${ }^{2}$, Youssef DIAB ${ }^{2}$, Laurent ROYON ${ }^{3}$ \\ ${ }^{1}$ Paris City Hall, Water and Sanitation Department, F-75014, Paris, France \\ ${ }^{2}$ Université Paris-Est, Lab’Urba, EA 3482, EIVP, F-75019, Paris, France \\ ${ }^{3}$ Univ Paris Diderot, Sorbonne Paris Cité, MSC, UMR 7057, CNRS, F-75013, Paris, France \\ *(corresponding author: martin.hendel@paris.fr)
}

\begin{abstract}
Pavement-watering as a technique of cooling dense urban areas and reducing the urban heat island effect has been studied since the 1990's. The method is currently considered as a potential tool for and climate change adaptation against increasing heat wave intensity and frequency. However, although water consumption necessary to implement this technique is an important aspect for decision makers, optimization of possible watering methods has only rarely been conducted. An analysis of pavement heat flux at a depth of $5 \mathrm{~cm}$ and solar irradiance measurements is proposed to attempt to optimize the watering period, cycle frequency and water consumption rate of a pavement-watering method applied in Paris over the summer of 2013. While fine-tuning of the frequency can be conducted on the basis of pavement heat flux observations, the watering rate requires a heat transfer analysis based on a relation established between pavement heat flux and solar irradiance during pavement insolation. From this, it was found that watering conducted during pavement insolation could be optimized to 30 -minute cycles and water consumption could be reduced by more than $80 \%$ while reducing the cooling effect by less than $13 \%$.
\end{abstract}

\section{Keywords}

Evaporative cooling; pavement heat flux; pavement-watering; urban heat island; climate change adaptation; heat wave

\section{Introduction}

Watering horizontal or vertical urban surfaces as a method for cooling urban spaces has been studied in Asia since the 1990s [1]-[6] and is only a recent topic in French cities such as Paris and Lyons [7]-[9]. With reported air temperature reductions ranging from $0.4^{\circ} \mathrm{C}$ at $2 \mathrm{~m}$ [8] to $4^{\circ} \mathrm{C}$ at $0.9 \mathrm{~m}$ [3], this technique is viewed as an efficient means of reducing urban heat island (UHI) intensity. In France and especially Paris, the predicted increases in heat wave intensity and frequency due to climate change [10], combined with the high sensitivity of dense cities to such episodes [11], [12], have focused efforts on the development of appropriate adaptation tools. In parallel to techniques such as green space development, pavement-watering is seen as one of these potential tools for heat-wave adaptation in mineral areas.

Pavement-watering implies the choice of a watering method and a corresponding urban infrastructure. For any given target-area, every watering method can be characterized by three parameters: the watering period, the watering rate and the watering frequency. The former indicates the period of each day during which pavement-watering is active, the second is the average amount of water delivered per unit area and per unit time (expressed in $\mathrm{mm} / \mathrm{h}$, equivalent to $L / \mathrm{m}^{2} . h$ ) and the last indicates the frequency of the watering cycles. Of these parameters, the watering rate is the one that defines the method's water consumption and is 
therefore important for decision-makers who face growing public pressure to reduce urban water use.

Several watering methods have been proposed or studied in the existing literature. For methods including vertical surface watering, a closed-loop watering system is usually designed. He and Hoyano [5] describe a building surface water supply of $12 \mathrm{~kg} /\left(\mathrm{m}^{2} . h\right)$ for watered building walls. Wei and He [6] conduct a similar simulation but include pavementwatering of a water-retaining pavement. The simulated water-retaining pavement is saturated at midnight, but no detail is given as to the amount of water required to saturate the waterretaining pavement. In 2008, the City of Paris funded a numerical research program aimed at testing different climate change adaptation strategies for heat wave events [7]. This work analyzed a daytime pavement-watering method based on a hypothetical infrastructure connected to the city's non-potable water network. Pavements and sidewalks were watered at a rate of $0.2 \mathrm{~mm} / \mathrm{h}$ for a duration of 3 minutes and frequency of every hour. During this work, a nighttime watering experiment was conducted over the summer of 2012 [8]. A single watering cycle of the pavement and sidewalk was conducted by cleaning truck around $10 \mathrm{pm}$ sprinkling $1 \mathrm{~L} / \mathrm{m}^{2}$, which is estimated by city officials as the maximum retention capacity of standard Parisian pavements. Field studies conducted in Nagoaka City, Japan used an existing snow-melting infrastructure which consists of a ground-water network used to water the road surface. Kinouchi and Kanda [1] ran this system continuously at a rate of $11 \mathrm{~mm} / \mathrm{h}$, while Takahashi et al. [3] ran it intermittently to deliver an average $2 \mathrm{~mm} / \mathrm{h}$ with 3-minute sprinkles, every 30 minutes. Yamagata et al. [4] used reclaimed waste water sprinkled onto a waterretentive pavement by temporary pipes placed on a central road planter. The watering method parameters are not specified in this study or in any of the other cited studies not mentioned in this paragraph.

Of these, only Takahashi et al. [3] and Météo-France and CSTB [7] describe attempts to optimize the watering method with atmospheric cooling parameters. Takahashi et al. [3] optimize both watering rate and frequency based on surface and $90-\mathrm{cm}$ air temperature observations over a period of one hour after watering. Météo-France and CSTB [7] base their own optimization on findings from Takahashi et al. with the hypothesis of a pavement waterholding capacity of $1 \mathrm{~mm}$. They optimize the watering rate based on 2-m air temperature simulations with a one-hour time step.

This paper looks into the optimization of an adapted version of Bouvier et al.'s [8] pavement-watering method by studying the pavement's thermal behavior. We will demonstrate how pavement heat flux measurements can be used to fine-tune the watering frequency, and how a surface heat transfer analysis combined with a linear relation found between heat flux and solar irradiance during pavement insolation can provide information on the watering rate. Measurements were obtained from one of two experimental sites in Paris over the summer of 2013. For this campaign, the rue du Louvre was equipped with a ground heat flux sensor which was placed $5 \mathrm{~cm}$ below the pavement surface as well as a pyranometer, and was watered several times during the day.

\section{Materials and Methods}

Conductive heat flux and surface temperatures were investigated on rue du Louvre, near Les Halles in the $1^{\text {st }}$ and $2^{\text {nd }}$ Arrondissements in Paris, France over the summer of 2013. Watered and control weather station positions are illustrated in Figure 1. Both watered and dry portions of the street are approximately $180 \mathrm{~m}$ long and $20 \mathrm{~m}$ wide. Rue du Louvre has an aspect ratio approximately equal to 1 and has a N-NE - S-SW orientation. 


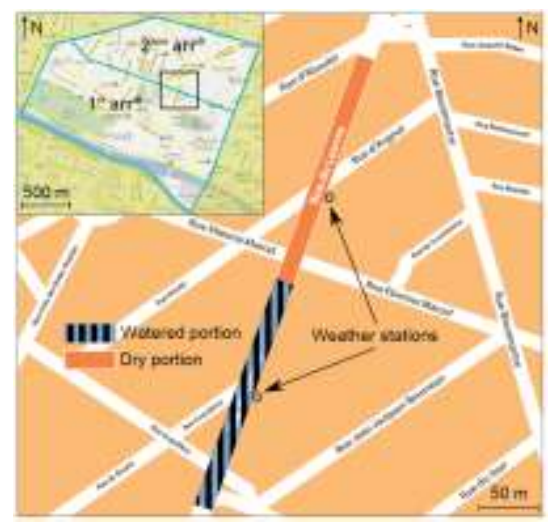

Figure 1: Map of the rue du Louvre site

All data is presented in local daylight savings time $($ UTC +2$)$. Statistical analyses were conducted using the $\mathrm{R}$ software environment, version 3.0.1. Because the control site was vandalized and thus rendered unoperational early during the experimental period, only watered station data on watered and dry (control) days will be discussed hereafter.

\subsection{Instruments}

The pavement at each site was equipped with a thermo-fluxmeter at a depth of $5 \mathrm{~cm}$. This sensor was connected to a weather station which functioned continuously for the duration of the summer and was used for additional microclimatic measurements which will not be discussed here. Figure 2 illustrates a top view of sensor installation. The weather station was positioned at the Eastern end of the cable.

The sensor was placed in the middle of the North-bound bus lane, causing no traffic disturbances once installed. Unauthorized parking and a 100-m distant traffic light ensured that only very limited shading or localized heat exhaust was caused by vehicles. Figure 3 shows a detailed cross-section of how the pavement sensor was set in place before filling.
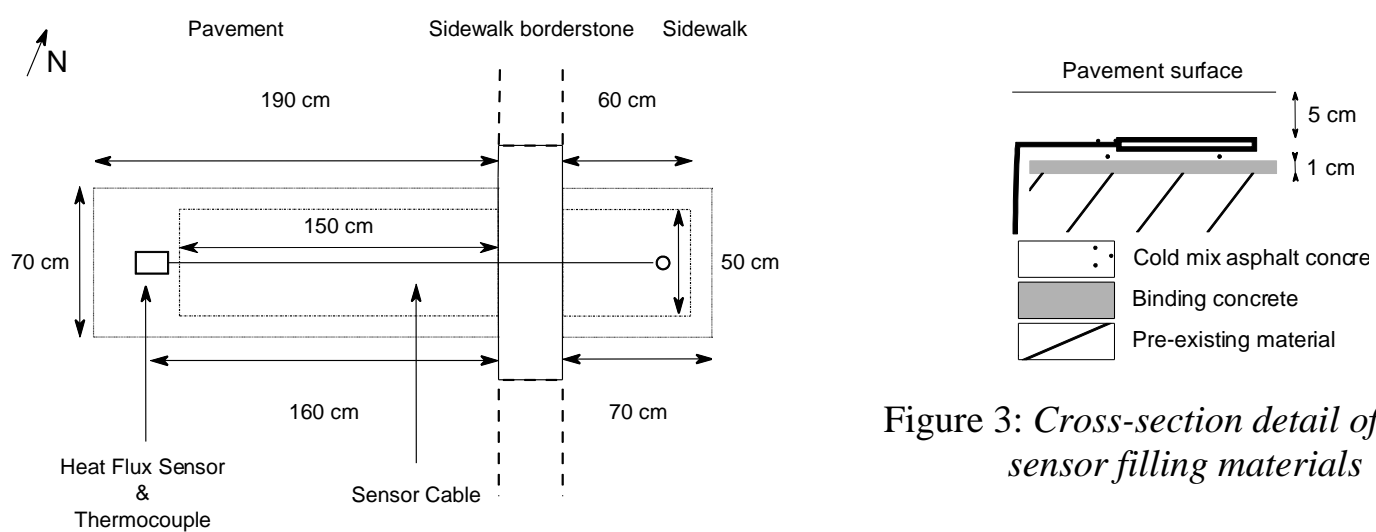

Figure 3: Cross-section detail of pavement sensor filling materials

Figure 2: Top view of pavement sensor

Table 1 summarizes the instruments and data used for the upcoming analyses.

\begin{tabular}{cccc}
\hline Parameter & Instrument & Height & Accuracy \\
\cline { 2 - 4 } Solar irradiance & $\begin{array}{c}\text { Second Class Pyranometer } \\
\text { ISO 9060 }\end{array}$ & $4 \mathrm{~m}$ & $10 \%$ daily \\
\cline { 2 - 4 } $\begin{array}{c}\text { Pavement heat } \\
\text { flux }\end{array}$ & Taylor-made flowmeter & $-5 \mathrm{~cm}$ & $5 \%$ \\
\hline
\end{tabular}




\subsection{Heat transfer analysis}

For the rest of this article, pavement heat flux density at a depth of $5 \mathrm{~cm}$ is referred to as $G$, solar irradiance measured by the pyranometer at a height of $4 \mathrm{~m}$ as $S^{\prime}$ 'and that received by the pavement as $S$. All measurements are made at 1-minute intervals. All daily data is presented over a 24-hour period spanning from 6 am until 5:59 am the following day in order to better outline the effect of pavement-watering, which began around 6:30 am.

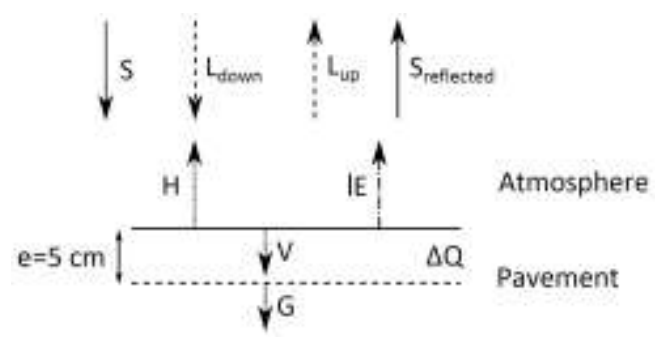

Figure 4: Diagram of pavement heat budget at surface

Figure 4, based on Kinouchi and Kanda [2], shows a diagram of the heat fluxes relevant to this experiment. Heat absorption by the water film is not illustrated but is taken into account in the last item of equation (3). In the case of excessive watering, significant runoff towards the sewer system may occur. The runoff water absorbs heat and transports to the sewers by advection.

Asaeda et al. [13] and Kinouchi and Kanda [2] characterize the energy balance of the pavement surface by the following equations:

$$
\begin{aligned}
& R_{n}^{d r y}=S+L_{\text {down }}-L_{u p}-S_{\text {ref }} \\
& R_{n}^{\text {dry }}=H^{d r y}+V^{d r y} \\
& R_{n}^{\text {wet }}=H^{\text {wet }}+V^{\text {wet }}+\Phi \\
& V=G+\Delta Q \\
& \Phi=l E+c \rho \frac{V_{s}}{t_{0}} T_{S}^{\text {wet }}-T_{W}
\end{aligned}
$$

$R_{n}$ is the net downward radiation received by the pavement surface and is the sum of the downward solar irradiance (shortwave radiation) $S$, downward longwave radiation $L_{\text {down }}$ and upward longwave radiation $L_{u p}$ and reflected shortwave radiation $S_{r e f} ; H$ is the upward atmospheric sensible heat flux; $V$ is the downward pavement heat flux at the surface; $\Phi$ is the heat flux absorbed by pavement-watering; $l$ is the latent heat of vaporization for water $(2,260 \mathrm{~kJ} / \mathrm{kg}) ; E$ is the evaporation rate; $c$ is the specific heat of water $(4.18 \mathrm{~kJ} / \mathrm{kg} . K) ; \rho$ is the density of water $\left(1,000 \mathrm{~kg} / \mathrm{m}^{3}\right) ; V_{S}$ is the water volume dispersed per unit surface area $\left(1 \mathrm{~L} / \mathrm{m}^{2}\right) ; t_{0}$ is the water cycle period in seconds; $T_{W}$ is the water temperature; $\Delta Q$ is the heat flux absorbed by the first $5-\mathrm{cm}$ layer of pavement. $\Phi$ designates the pavement-watering cooling flux.

By subtracting equations (2) and (3):

$\Phi=H^{d r y}-H^{w e t}+V^{d r y}-V^{w e t}+L_{u p}^{d r y}-L_{u p}^{w e t}+S_{r e f}^{d r y}-S_{r e f}^{w e t}$

According to Jürges' formula [14], convective heat flux can be written as:

$H=h\left(T_{S}-T_{\text {air }}\right)$ 
$T_{S}$ is the surface temperature of the pavement and $T_{a i r}$ is that of the air above it. $h$ is the convective heat transfer coefficient.

Furthermore, following the Stefan-Boltzmann law and infrared reflection, $L_{u p}$ can be expressed as:

$L_{\text {up }}=\varepsilon \sigma T_{S}^{4}+1-\varepsilon L_{\text {down }}$

$\varepsilon$ is the emissivity of the emitting surface, while $\sigma$ is Boltzmann's constant.

By definition, $S_{r e f}$ can be expressed as:

$S_{\text {ref }}=a S$

Where $a$ is the surface albedo, i.e. its shortwave reflectance.

Hence:

$$
\begin{aligned}
& L_{u p}^{d r y}-L_{u p}^{w e t}=\sigma \varepsilon_{d} T_{S}^{d r y^{4}}-\varepsilon_{w} T_{S}^{w e t^{4}}+\varepsilon_{w}-\varepsilon_{d} L_{\text {down }} \\
& S_{r e f}^{d r y}-S_{r e f}^{w e t}=a_{d}-a_{w} S
\end{aligned}
$$

From these equations, the following can be derived:

$$
\begin{aligned}
\Phi & =h T_{S}^{d r y}-T_{S}^{w e t}+T_{\text {air }}^{\text {wet }}-T_{\text {air }}^{d r y}+V_{\text {dry }}-V_{\text {wet }}+\sigma \varepsilon_{d} T_{S}^{d r y^{4}}-\varepsilon_{w} T_{S}^{\text {wet }}{ }^{4}+\varepsilon_{w}- \\
\varepsilon_{d} L_{\text {down }} & +a_{d}-a_{w} S
\end{aligned}
$$

The resulting heat budget is analogous to that used by He and Hoyano [5] and Wei and He [6] for a vertical surface with a water film.

Therefore, knowledge of $G, \Delta Q, L_{\text {down }}, S, h$, air, water and pavement surface temperatures and pavement emissivity and albedo under dry and wet conditions allows an estimation of the latent heat flux and thus the evaporation rate.

Unfortunately, $L_{\text {down }}$ was not measured. In dry conditions, the asphalt surface's emissivity $\left(\varepsilon_{d}\right)$ was measured to be 0.97 , while in wet conditions the surface's emissivity $\left(\varepsilon_{w}\right)$ is that of water, equal to 0.98 . Because the difference in emissivity between the wet and dry pavements is minor, it is neglected in the second term of equation (10). Thus:

$$
L_{u p}^{d r y}-L_{u p}^{w e t}=\sigma \varepsilon_{d} T_{S}^{d r y^{4}}-\varepsilon_{w} T_{S}^{w e t^{4}}
$$

Furthermore, pavement albedo was not measured either. According to Santamouris, the typical albedo range for asphalt is 0.05 to 0.20 , the former value referring to new asphalt pavements, the latter to older ones [15]. Because of the road work necessary to lay the pavement sensor, the pavement above it was practically new. We therefore assume an albedo of 0.05 in dry conditions. According to Lekner and Dorf [16], since $a_{d} \ll 1$, both dry and wet asphalt have approximately equal albedos: $a_{w} \approx a_{d}$. Therefore: $S_{\text {ref }}^{\text {dry }}-S_{\text {ref }}^{\text {wet }} \approx 0$. This holds true for the rest of the pavement surface as well if an albedo of 0.10 is assumed.

Finally, several empirical formulae exist to calculate $h$ based on wind speed, $v$ (in $\mathrm{m} / \mathrm{s}$ ). These include $h=6.15+4.18 v$ used by Kusaka et al. [17] and $h=5.7+3.8 v$ in Duffie and Beckman [18]. Under the field conditions described (hourly wind speed approximately equal to $1 \mathrm{~m} / \mathrm{s}), h$ is approximately equal to $10 \mathrm{~W} / \mathrm{m} . \mathrm{K}$.

With these approximations, the following equation is obtained:

$$
\Phi=h T_{S}^{d r y}-T_{S}^{\text {wet }}+T_{\text {air }}^{\text {wet }}-T_{\text {air }}^{d r y}+\sigma \varepsilon_{d} T_{S}^{d r y^{4}}-\varepsilon_{w} T_{S}^{\text {wet }}{ }^{4}+V_{d r y}-V_{\text {wet }}
$$


Thus, knowledge of $G, \Delta Q$, air, water and pavement surface temperatures under dry and wet conditions is sufficient to estimate the latent heat flux.

As defined, $\Phi$ has two components, a latent flux component and an advective flux component. Both components are positive and are dependent on the watering rate $V_{S} / t_{0}$.

The analysis of the mass convection transport problem can also be used to estimate the evaporation rate, although it is inadequate at optimizing the watering frequency. This method assumes that evaporation is uninterrupted, i.e. that the watered surface does not dry out. Pagliarini and Rainieri use such a method to determine the evaporation rate on a continuously-watered glass roof [19]. Adapted to our problem by assuming that the water film and the road surface have the same temperature, their equation becomes:

$$
l E=0.622 \frac{l h}{c_{p} p_{0}} T_{S}^{w e t} \frac{p_{S}}{T_{S}^{w e t}}-\frac{p_{v}}{T_{a i r}^{w e t}}
$$

$p_{0}, p_{s}$ and $p_{v}$ represent total air pressure, saturation vapor pressure at the water film temperature $T_{s}^{\text {wet }}$ and partial air vapor pressure at $T_{\text {air }}{ }^{\text {wet }}$ in $P a$, respectively. $c_{p}$ is air specific heat $(1.005 \mathrm{~J} / \mathrm{g} . \mathrm{K})$.

The meteorological data required to solve this equation was not measured at the rue du Louvre site. The best available data is provided by Météo-France's Montsouris weather station and consists of hourly measurements.

This approach will be used to confront the results obtained from the heat transfer analysis.

\subsection{Watering method and optimization goals}

Watering was started if certain weather conditions were met based on Météo-France's three-day forecast. These as well as those for heat-wave warnings are presented in Table 2 .

\begin{tabular}{|c|c|c|}
\hline Parameter & Pavement-watering & Heat-wave warning level \\
\hline $\begin{array}{l}\text { Mean 3-day minimum } \\
\text { air temperature }\left(B M I_{M i n}\right)\end{array}$ & $>16^{\circ} \mathrm{C}$ & $>21^{\circ} \mathrm{C}$ \\
\hline $\begin{array}{l}\text { Mean 3-day maximum } \\
\text { air temperature }\left(B M I_{M a x}\right)\end{array}$ & $>25^{\circ} \mathrm{C}$ & $>31^{\circ} \mathrm{C}$ \\
\hline Wind speed & $<10 \mathrm{~km} / \mathrm{h}$ & - \\
\hline Sky conditions & Sunny (less than 2 oktas clou & - \\
\hline
\end{tabular}

Table 2: Weather conditions required for pavement-watering and heat wave warnings

Cleaning trucks were used to sprinkle approximately $1 \mathrm{~mm}\left(V_{S}\right)$ every hour from 6:30 am to $11: 30$ am and every 30 minutes from $2 \mathrm{pm}$ until $6: 30 \mathrm{pm}$ on the sidewalk and pavement. $1 \mathrm{~mm}$ is considered to be the maximum water-holding capacity of the pavement. Watering times were reported by truck operators and cross-checked against visible images taken by a rooftop thermal camera. Resulting watering time precision is estimated to be no better than 5 minutes.

Water used for this experiment was supplied by the city's $1,600 \mathrm{~km}$ non-potable water network, principally sourced from the Ourcq Canal. Although water temperature was not measured, its summertime range is reported by city services to be $20^{\circ}-25^{\circ} \mathrm{C}$.

In this situation, the goals chosen for optimization were, by order of importance:

- Minimize the watering frequency, i.e. maximize $t_{0}$

- Maximize obtained pavement cooling, $\Phi$ 
- Minimize the watering rate, ${ }^{V_{S}} t_{0}$

The last two goals can be recombined as "Minimize the watering rate to pavement cooling ratio, $\frac{V_{S}}{t_{0}} \Phi . "$

Direct pavement heat flux analysis is sufficient for the frequency optimization, while a heat transfer analysis is necessary to estimate the effect of pavement-watering and to optimize water consumption. The heat transfer analysis requires a preliminary analysis of pavement heat flux measurements.

\subsection{Derivation of pavement solar irradiance from measured solar irradiance}

$S^{\prime}$ was measured continuously starting on July $2^{\text {nd }}, 2013$. Because of the difference in positioning of the pyranometer and the pavement sensor, $S^{\prime}$ is not equal to $S$ and can therefore not be used in its place for the heat transfer analysis. $S$ must therefore be derived from $S$ '.

Apart from possible insolation interruptions due to road traffic not visible in $S^{\prime}$, the only difference is the insolation period. The visible images taken by an infrared rooftop camera reveal a 20-minute-long time lag between the beginning of pavement sensor and pyranometer insolation during the month of July. The time lag is immediately identifiable when comparing the graphs of $G$ and $S^{\prime}$ for July $11^{\text {th }}$ in Figure 5. The beginning and end of pavement and pyranometer insolation are illustrated by the two dashed and long-dashed vertical lines, respectively. These coincide with the sudden increases and declines seen in each signal. The insolation period of the pavement is approximately $1: 35 \mathrm{pm}$ to $6: 30 \mathrm{pm}$, while that of the pyranometer is $1: 55 \mathrm{pm}$ to $6: 50 \mathrm{pm}$. No signal distortion other than the time lag is expected or taken into account.
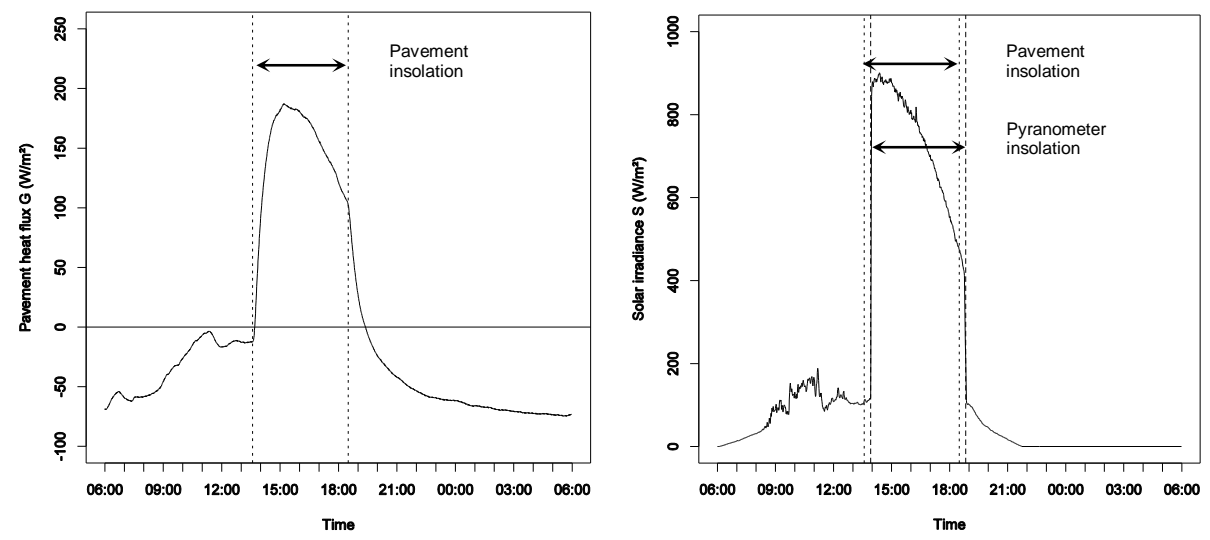

Figure 5: G (left) and S' (right) measured on July $11^{\text {th }}$.

With these hypotheses, a modification of $S$ ' during the two 20-minute exclusive disjunctions of pyranometer and pavement insolation is undertaken to obtain $S$. The rest of the signal is unchanged, apart for distortions due to vehicles. Finally, to ensure signal continuity, the 5 minutes following and/or preceding these 20-minute periods are also modified.

\section{Watering period and frequency}

Pavement heat flux density data from the watered station will now be compared between watered days and days without watering (control days). These observations will help infer conclusions on the watering frequency. All selected days are of Pasquill Stability Class A (i.e. strong daytime insolation and surface wind speeds below $2 \mathrm{~m} / \mathrm{s}$ ) [20]. 


\subsection{Results}

\subsubsection{Control days}

The evolution of $G$ and $S$ on July $11^{\text {th }}, 14^{\text {th }}$, and $20^{\text {th }}$ are presented in Figure $6 . S$ ranges from $0 \mathrm{~W} / \mathrm{m}^{2}$ to $200 \mathrm{~W} / \mathrm{m}^{2}$ during shading and from $200 \mathrm{~W} / \mathrm{m}^{2}$ to $900 \mathrm{~W} / \mathrm{m}^{2}$ during direct insolation. $G$ ranges from $-75 \mathrm{~W} / \mathrm{m}^{2}$ to $215 \mathrm{~W} / \mathrm{m}^{2}$.

In terms of heat flux, each day can be divided into three periods: two of net heat release $(G<0)$ in the morning and evening and one of net heat storage $(G>0)$ during the day. The net release of heat by the pavement lasts about 18 hours, while heat is during the remaining 6 hours, approximately between 1:30 pm and $7 \mathrm{pm}$.

When the sun starts to hit the pavement, $G$ enters a transient period during which the top $5 \mathrm{~cm}$ layer of pavement begins to store heat, i.e. during which $\Delta Q \neq 0$. The transient period is outlined by the first dotted vertical line in Figure 7 and the peak in heat flux. The last dashed vertical line indicates the instant when the pavement is shaded, at 6:30 pm. After the transient period, $G$ and $S$ follow a similar trend.
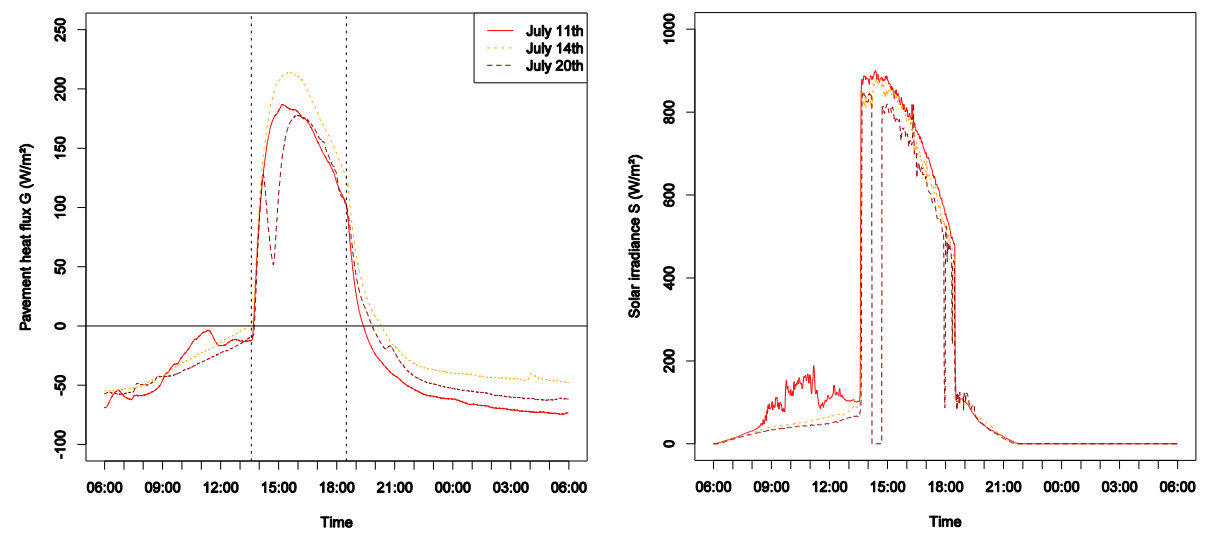

Figure 6: Pavement heat flux G (left) and shortwave radiation S (right) on control days.

It should be noted that an illegally-parked vehicle covered the pavement sensor for 30 minutes on July $20^{\text {th }} . S$ was been corrected in order to take this into account.

\subsubsection{Watered days}

Watered days will now be considered in the following order: July $8^{\text {th }}, 22^{\text {nd }}$ and $10^{\text {th }}$. Figure 8 illustrates $G$ and $S$ on those dates. Long-dashed vertical lines represent watering cycles. $S$ is in the same range as found on control days, while $G$ ranges from $-75 \mathrm{~W} / \mathrm{m}^{2}$ to $130 \mathrm{~W} / \mathrm{m}^{2}$.

The watering methods applied in the afternoon on watered days and the daily maximum value of $G$ is summarized in Table 3 . Watering cycles occurred at the specified frequencies except for a 50-minute interruption on July $22^{\text {nd }}$ at approximately $3 \mathrm{pm}$.

\begin{tabular}{|c|c|c|c|}
\hline Watering method parameter & July $8^{\text {th }}$ & July $22^{\text {nd }}$ & July $10^{\text {th }}$ \\
\hline Watering rate $(\mathrm{mm} / \mathrm{h})$ & 1.33 & 2 & 2 \\
\hline Watering period $(\mathrm{min})$ & 45 & 30 & 30 \\
\hline Delay of watering vs. start of insolation ( $\mathrm{min}$ ) & 35 & 65 & $<5$ \\
\hline Daily maximum value of $G\left(\mathrm{~W} / \mathrm{m}^{2}\right)$ & 115 & 130 & 70 \\
\hline
\end{tabular}

Table 3: Actual watering method on considered watered days 

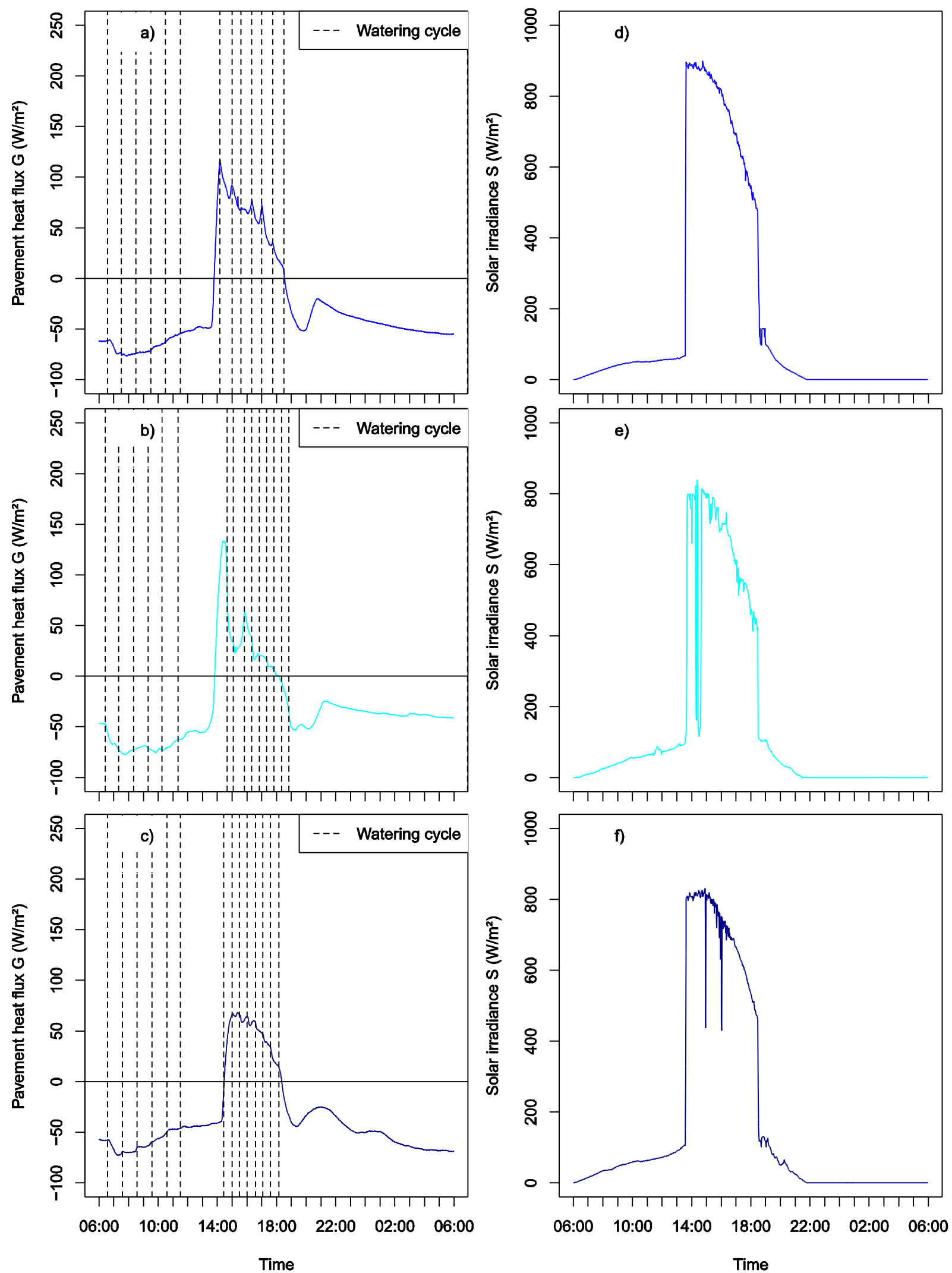

Figure 7: Pavement heat flux $\mathrm{G}$ and shortwave radiation $\mathrm{S}$ on watered days. a) and d) July $8^{\text {th }}$; $b$ ) and e) July $22^{\text {nd }}$ c) and f) July $10^{\text {th }}$

The maximum value of $G$ is about half that reached on control days, ranging from $70 \mathrm{~W} / \mathrm{m}^{2}$ to $130 \mathrm{~W} / \mathrm{m}^{2}$, approximately half that observed on control days. The daily peak in $G$ is found to coincinde with the beginning of afternoon watering, except on July $10^{\text {th }}$ when afternoon 
watering began simultaneously to insolation. Furthermore, the observed reduction is inversely proportional to the delay between the start of afternoon watering and the start of pavement insolation. In other words, the later afternoon pavement-watering begins, the higher the daily peak in $G$. Between $3 \mathrm{pm}$ and 6:30 pm, the average reduction in pavement heat flux compared to different reference control days is found to be between 100 and $150 \mathrm{~W} / \mathrm{m}^{2}$. Table 4 summarizes these reductions. In the morning, $G$ is reduced by approximately $15 \mathrm{~W} / \mathrm{m}^{2}$.

\begin{tabular}{|c|c|c|c|c|c|c|}
\hline Date & \multicolumn{2}{|c|}{ July $8^{\text {th }}$} & \multicolumn{2}{|c|}{ July $22^{\text {nd }}$} & \multicolumn{2}{|c|}{ July $10^{\text {th }}$} \\
\hline Control day (refer & July $11^{\text {th }}$ & July $14^{\text {th }}$ & July $14^{\text {th }}$ & July $20^{\text {th }}$ & July $11^{\text {th }}$ & July $14^{\text {th }}$ \\
\hline Average reduction $\left(\mathrm{W} / \mathrm{m}^{2}\right)$ & -100 & -120 & -130 & -150 & -110 & -130 \\
\hline
\end{tabular}

Table 4: Average heat flux density reduction in $\mathrm{W} / \mathrm{m}^{2}$ on watered days

\subsection{Discussion}

The comparison of $G$ on watered days with control days revealed strong effects due to pavement-watering. On the one hand, heat flux density reductions were found to be highest in the afternoon during pavement insolation with $G$ being more than halved. The average reduction is between 100 and $150 \mathrm{~W} / \mathrm{m}^{2}$ during this period. Morning heat flux density, when the pavement is shaded, was also reduced by pavement-watering in the order of $15 \mathrm{~W} / \mathrm{m}^{2}$. On the other hand, the daily peak in $G$ was found to coincide with the first afternoon watering cycle and to be proportional to the delay between this cycle and pavement insolation. Furthermore, spikes in $G$ were observed if watering cycles were more than 45 minutes apart.

This provides insight on two aspects of the watering method: its watering period and its frequency. First, the value of the daily maximum of $G$ depends on the start of afternoon watering relatively to pavement insolation. Second, if the pavement watering frequency is too low, the pavement surface has enough time to dry and $G$ rises towards its normal control value until the next watering cycle.

In order to maximize pavement cooling in the afternoon, watering should begin just a few minutes prior to pavement insolation. Furthermore, the watering frequency must be adjusted to prevent the pavement surface from drying. These observations suggest that a period of 45 minutes is too long, while 30 minutes is nearly optimal during insolation. In the morning, in shaded conditions, the data suggests that watering every hour is sufficient, perhaps optimal.

Overall, these observations are consistent with previous work. On control days, the trend in heat flux is comparable to measurements made without pavement-watering by Kinouchi and Kanda [2], also $5 \mathrm{~cm}$ deep, although inside a porous pavement. The heat flux values are about twice as large as what Asaeda et al. [13] observed $20 \mathrm{~cm}$ below the asphalt pavement surface. Given the difference in depth, this discrepancy is not considered surprising. On watered days, observations are similar to those of Kinouchi and Kanda [1], [2] as well: the first watering cycle on all watered days coincides with a small "nose-dive" in $G$ in the order of $15 \mathrm{~W} / \mathrm{m}^{2}$. Lastly, the net storage period observed in this experiment is shorter than in reports from Kinouchi and Kanda [2] or Asaeda et al. [13], but they were working in nearly unmasked conditions.

\section{Watering rate}

Kinouchi and Kanda [2] put into perspective a correlation between $R_{n}$ and $G$. They proceeded by plotting $G$ as a function of $R_{n}$. Camuffo and Bernardi [21] explore the hysteris cycles found between surface heat fluxes and net radiation for soil. Other authors such as 
Asaeda et al. [13], studying the effect of pavement heat storage on the lower atmosphere, also look into this hysteris cycle for asphalt and concrete pavements. Because net radiation was not measured, we shall proceed in an analoguous fashion with $S$ instead. This will permit the estimation of the surface cooling effect of pavement-watering based on a relation between $S$ and $G$ during pavement insolation. From this an estimate of the evaporation rate is obtained and therefrom watering rate adjustment recommandations can be made.

\subsection{Results}

Figure 8 shows $G$ as a function of $S$ on a) July $11^{\text {th }}$, b) July $14^{\text {th }}$, c) July $20^{\text {th }}$, d) July $8^{\text {th }}$, e) July $22^{\text {nd }}$ and f) July $10^{\text {th }}$. The chronological order of the data points is anti-clockwise. The least square regression line of $G$ according to $S$ between $3 \mathrm{pm}$ and $6: 30 \mathrm{pm}$, when the pavement has been both insolated and watered for at least 30 minutes, is plotted for each date.

The parameters from the linear regression can be formalized as:

$G=\alpha S+G_{0}$

$\alpha$ is the conversion coefficient of solar irradiance to pavement heat flux $5 \mathrm{~cm}$ below the pavement surface, while $G_{0}$ is the intercept heat flux under these conditions.

The regressions were conducted for control and watered days. On control days, an intercept of $0 \mathrm{~W} / \mathrm{m}^{2}$ was used. Table 5 summarizes the regression parameters for control days.

\begin{tabular}{cccc}
\hline Date & July $^{2} 11^{\text {th }}$ & July $14^{\text {th }}$ & July $20^{\text {th }}$ \\
\cline { 3 - 4 }$\alpha$ & 0.222 & 0.271 & 0.247 \\
\cline { 2 - 4 }$R^{2}$ & 0.999 & 0.998 & 0.986 \\
\hline \multicolumn{4}{c}{ Table 5: $\alpha$ and $\mathrm{R}^{2}$ on control days }
\end{tabular}

Each fit is statistically significant, with coefficients of determination in excess of 0.98 . Overall, the conversion coefficients derived on control days range from $22 \%$ to $27 \%$.

On watered days, different intercepts, corresponding to the average reduction of $G$ found in Table 4, were tested. Using these intercepts, similar slopes to those found on control days were obtained. Table 6 summarizes the regression parameters using the different intercepts for watered days.

\begin{tabular}{ccccccc}
\hline Date & \multicolumn{2}{c}{ July $8^{\text {th }}$} & \multicolumn{2}{c}{ July $22^{\text {nd }}$} & \multicolumn{2}{c}{ July $10^{\text {th }}$} \\
\hline $\begin{array}{c}\text { Control day } \\
G_{0}\left(\mathrm{~W} / \mathrm{m}^{2}\right)\end{array}$ & ${\text { July } 11^{\text {th }}}$ & $\mathrm{Jull}^{\text {th }}$ & ${\text { July } 14^{\text {th }}}^{\text {July } 20^{\text {th }}}$ & ${\text { July } 11^{\text {th }}}^{\text {July } 14^{\text {th }}}$ \\
\cline { 2 - 8 } & -100 & -120 & -130 & -150 & -110 & -130 \\
\hline$R^{2}$ & 0.216 & 0.244 & 0.237 & 0.269 & 0.232 & 0.262 \\
\hline & 0.997 & 0.995 & 0.986 & 0.985 & 0.996 & 0.996 \\
\hline
\end{tabular}

Table 6: $\alpha, \mathrm{R}^{2}$ and $\mathrm{G}_{0}$ on watered days. The value of $\mathrm{G}_{0}$ was input by the user.

Regardless of the intercept value used, the conversion coefficients deviate only slightly from those derived on control days, remaining in the same $22-27 \%$ range. Considering the statistical significance of these regression parameters, it is concluded that pavement-watering does not significantly affect the conversion coefficient, but adds a constant heat flux, $G_{0}$. 

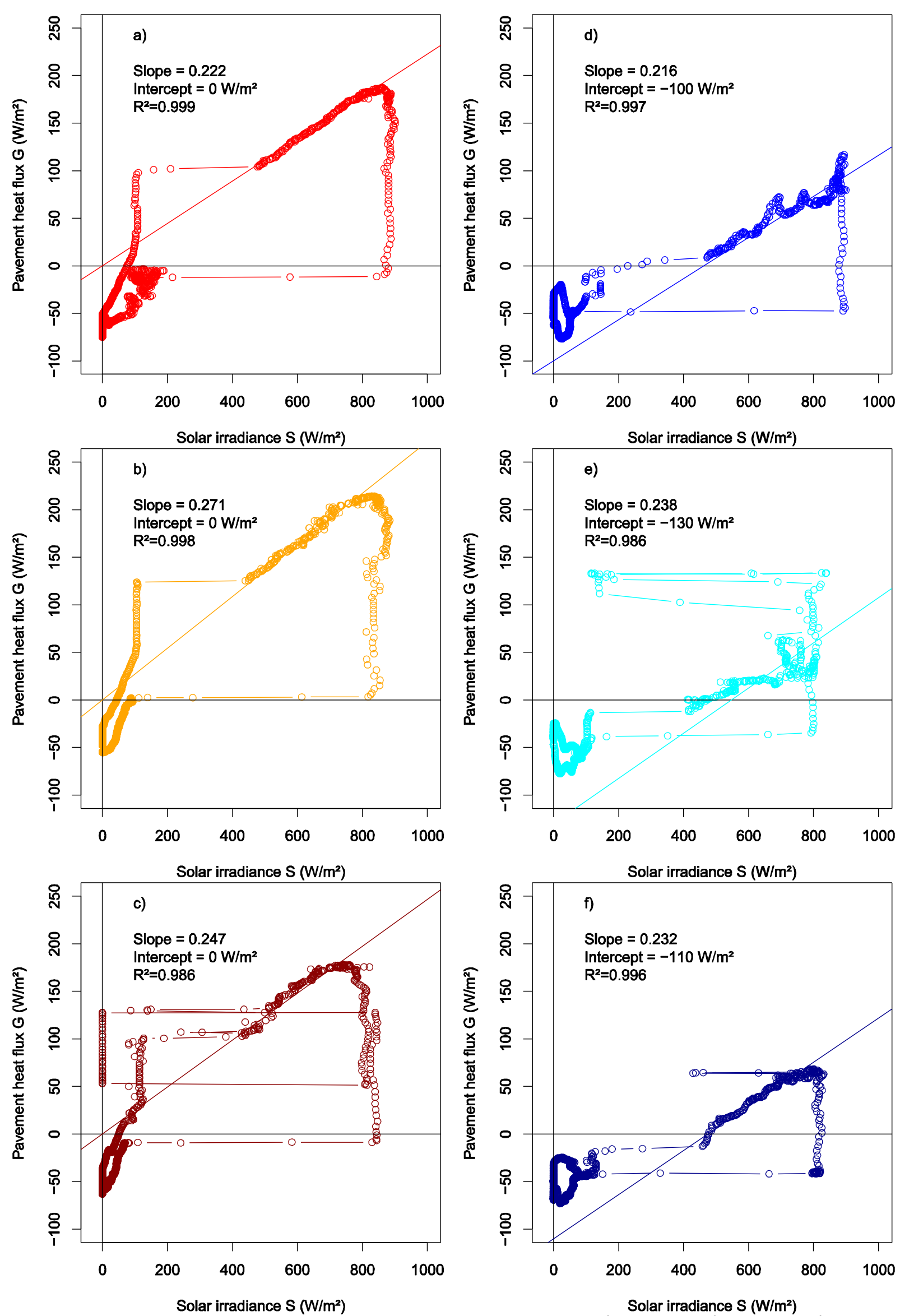

Figure 8: $\mathrm{G}$ as a function of $\mathrm{S}$ on control and watered days. a) July $11^{\text {th }}$, b) July $14^{\text {th }}$, c) July $20^{\text {th }}, d$ ) July $8^{\text {th }}$, e) July $22^{\text {nd }}$, f) July $10^{\text {th }}$. 
Solar energy is therefore transmitted in the same manner $5 \mathrm{~cm}$ below the pavement surface when wet or dry up to a constant. It can therefore be assumed that $\Delta Q$ is unchanged by watering during insolation, i.e. $\Delta Q_{w e t}=\Delta Q_{d r y}$. In other words, $V$ is also unchanged up to the same constant as $G$ when dry or watered in insolated conditions. This hypothesis is in agreement with experimental data presented by Kinouchi and Kanda [2], which illustrate that $\Delta Q$ is unaffected by pavement-watering.

This information allows the estimation of the cooling created by the sprinkled water. The contribution from water advection is found to be between 23 and $35 \mathrm{~W} / \mathrm{m}^{2}$, while that of evaporation is $269-341 \mathrm{~W} / \mathrm{m}^{2}$.

This is derived by using the regression parameters from equation (16) in equation (14), resulting in the following equation:

$$
l E+c \rho \frac{V_{S}}{t_{0}} T_{S}^{\text {wet }}-T_{W}=h T_{S}^{d r y}-T_{S}^{w e t}+T_{\text {air }}^{\text {wet }}-T_{\text {air }}^{\text {dry }}+\sigma \varepsilon_{d} T_{S}^{d r y^{4}}-\varepsilon_{w} T_{S}^{\text {wet }}{ }^{4}-G_{0}
$$

As stated in the introduction, previous studies of pavement-watering report air temperature reductions of up to $4^{\circ} \mathrm{C}$ [1]-[8]. It is assumed that $-2^{\circ} \mathrm{C} \leq T_{\text {air }}^{\text {wet }}-T_{\text {air }}^{d r y} \leq 0$ for the purpose of this analysis. Uncertainty propagation due to estimated parameters such as this one is integrated following Kline and McClintock [22].

In addition, collected pavement surface temperature data (not discussed here, for further details the authors refer the reader to [23]) reveal an average reduction during insolation of $13^{\circ} \mathrm{C}$, from $50^{\circ} \mathrm{C}(323 \mathrm{~K})$ to $37^{\circ} \mathrm{C}(310 \mathrm{~K})$. These findings agree well with observations made by Kinouchi and Kanda [1] and Wei and He [6]. Having found that $h=10 \mathrm{~W} / \mathrm{m}^{2} . K$, and considering that $110 \mathrm{~W} / \mathrm{m}^{2} \leq-G_{0} \leq 150 \mathrm{~W} / \mathrm{m}^{2}$ on days with the optimal 30-minute watering:

$$
304 \mathrm{~W} / \mathrm{m}^{2} \leq l E+c \rho \frac{V_{S}}{t_{0}} T_{S}^{\text {wet }}-T_{W} \leq 364 \mathrm{~W} / \mathrm{m}^{2}
$$

As stated previously, past non-potable water analyses conducted by the city services have shown that its temperature is in the $20-25^{\circ} \mathrm{C}$ range on hot summer days. Assuming that the runoff temperature increases to $35^{\circ} \mathrm{C}$ by contact with the pavement:

$$
\begin{aligned}
& 23 \mathrm{~W} / \mathrm{m}^{2} \leq c \rho \frac{V_{S}}{t_{0}} T_{S}^{w e t}-T_{W} \leq 35 \mathrm{~W} / \mathrm{m}^{2} \\
& 269 \mathrm{~W} / \mathrm{m}^{2} \leq l E \leq 341 \mathrm{~W} / \mathrm{m}^{2}
\end{aligned}
$$

Considering a latent heat of vaporization of $2,260 \mathrm{~kJ} / \mathrm{kg}$, it can be asserted that the evaporation rate is between 0.119 and $0.151 \mathrm{~g} / \mathrm{m}^{2} . \mathrm{s}$, i.e. between 0.43 and $0.54 \mathrm{~mm} / \mathrm{h}$. This means that for each 30-minute watering cycle, 0.21 to $0.27 \mathrm{~mm}$ evaporate. Since the preliminary pavement heat flux analysis has shown that the pavement dries off after 30 minutes, it can be asserted that the rest of the water runs off into the sewer system.

\subsection{Confrontation with the mass convection transport problem}

The previous solution will now be compared to the solutions obtained with the mass convection transport problem. Table 7 provides the relevant meteorological parameters and the solutions obtained by solving equation (15) for days with 30-minute watering, i.e. July $22^{\text {nd }}$ and $10^{\text {th }}, 2013$. The values indicated are the averages of each parameter recorded by Météo-France at their Montsouris station between $3 \mathrm{pm}$ and 6:30 pm.

As can be seen from Table 7, the evaporation rates thus obtained are about three times higher than those obtained by solving the heat transfer problem. Since both methods were 
taken from the existing literature and are rigorous, they should agree if the shared parameters and assumptions are correct.

\begin{tabular}{ccc}
\hline Date & July $22^{\text {nd }}$ & July $10^{\text {th }}$ \\
\hline$p_{0}(\mathrm{~Pa})$ & 100,500 & 100,900 \\
\cline { 2 - 3 }$T_{s}^{\text {wet }}(\mathrm{K})$ & 310 & 310 \\
\cline { 2 - 3 }$T_{\text {air }}(\mathrm{K})$ & 306 & 299 \\
\cline { 2 - 3 } Relative Humidity & $33 \%$ & $45 \%$ \\
\cline { 2 - 3 }$p_{s}(\mathrm{~Pa})$ & 6,295 & 6,295 \\
\cline { 2 - 3 }$p_{v}(\mathrm{~Pa})$ & 1,665 & 1,516 \\
\cline { 2 - 3 }$l E\left(\mathrm{~W} / \mathrm{m}^{2}\right)$ & 641 & 655 \\
\hline$E\left(\mathrm{~g} / \mathrm{m}^{2} \mathrm{~s}\right)$ & 0.284 & 0.290 \\
\hline
\end{tabular}

Table 7: Average value of meteorological parameters on July $22^{\text {nd }}$, and $10^{\text {th }}, 2013$ between $3 \mathrm{pm}$ and 6:30 pm and corresponding solutions to equation (15)

One implicit shared assumption is that evaporation at the pavement surface is continuous between $3 \mathrm{pm}$ and $6: 30 \mathrm{pm}$. Since the pavement remained wet in between watering cycles, this assumption is correct and is therefore not the cause of the observed discrepancy.

The only remaining shared parameter that must therefore have been incorrectly estimated is the convective heat transfer coefficient $h$. Good agreement between both methods is found if $h$ is assumed equal to $3.5 \mathrm{~W} / \mathrm{m}^{2} . K$.

Previous overestimation of $h$ is attributed to the use of 4-m wind speed measurements. They appear to be too different from wind conditions closer to the pavement to be representative of the convective transfers taking place locally. Although $3.5 \mathrm{~W} / \mathrm{m}^{2} . K$ may seem rather low, it should be noted that the weather conditions under which pavementwatering was conducted are chosen to be representative of heat waves, with high temperatures and insolation and low wind speeds. They are therefore not representative of typical weather conditions for Paris. This also explains the low relative humidity observed on these two days.

Table 8 presents the results from the mass convection transport problem with the corrected convective transfer coefficient.

\begin{tabular}{ccc}
\hline Date & July $22^{\text {nd }}$ & July $10^{\text {th }}$ \\
\hline$l E\left(\mathrm{~W} / \mathrm{m}^{2}\right)$ & 224 & 229 \\
\cline { 2 - 3 } & 224 & 0.101 \\
\hline
\end{tabular}

Table 8: Solutions to equation (15) obtained with $\mathrm{h}=3.5 \mathrm{~W} / \mathrm{m}^{2} \cdot \mathrm{K}$

With $h=3.5 \mathrm{~W} / \mathrm{m}^{2} . K$, total pavement cooling found using equation (17) amounts to between 232 and $279 \mathrm{~W} / \mathrm{m}^{2}$, divided between water advection and evaporation as follows:

$$
\begin{aligned}
& 23 \mathrm{~W} / \mathrm{m}^{2} \leq c \rho \frac{V_{s}}{t_{0}} T_{S}^{\text {wet }}-T_{W} \leq 35 \mathrm{~W} / \mathrm{m}^{2} \\
& 198 \mathrm{~W} / \mathrm{m}^{2} \leq l E \leq 256 \mathrm{~W} / \mathrm{m}^{2}
\end{aligned}
$$


This corresponds to an evaporation rate of between 0.087 and $0.113 \mathrm{~g} / \mathrm{m}^{2} . \mathrm{s}$, i.e. between 0.31 and $0.41 \mathrm{~mm} / \mathrm{h}$. This means that for each 30-minute watering cycle 0.16 to $0.20 \mathrm{~mm}$ of water evaporate.

\subsection{Discussion}

The analysis of $G$ as a function of $S$ during insolation after the initial transient period has allowed the demonstration that pavement-watering accounts for 232 to $279 \mathrm{~W} / \mathrm{m}^{2}$ of pavement surface cooling. At least $85 \%$ of total cooling attributable to pavement-watering is produced by evaporation, $15 \%$ at most is produced by water advection.

The relative contributions of advection and evaporation contrast strongly with the amount of water used by each of these phenomena which is respectively $2 \mathrm{~mm} / \mathrm{h}$ and 0.31 to $0.41 \mathrm{~mm} / \mathrm{h}$. Pavement cooling by water advection is therefore much less water efficient than that from evaporation: 12 to $18 \mathrm{~W} / \mathrm{m}^{2}$ of cooling per $1 \mathrm{~mm} / \mathrm{h}$ of sprinkled water, compared to $628 \mathrm{~W} / \mathrm{m}^{2}$ per $1 \mathrm{~mm} / \mathrm{h}$ of evaporated water. However, evaporation cannot increase past a certain value, dependent on the local meteorological conditions.

Figure 9 illustrates pavement cooling $\Phi$ (left) and the watering rate to cooling ratio (right) according to the watering rate, assuming a constant water and pavement surface temperature differential and a maximum evaporation rate of $0.41 \mathrm{~mm} / \mathrm{h}$. The $0.41 \mathrm{~mm} / \mathrm{h}$ mark is emphasized by the long-dashed vertical lines in Figure 9. It is clear that once evaporation has been maximized, pavement cooling is only marginally increased by additional watering as the advective contribution increases.
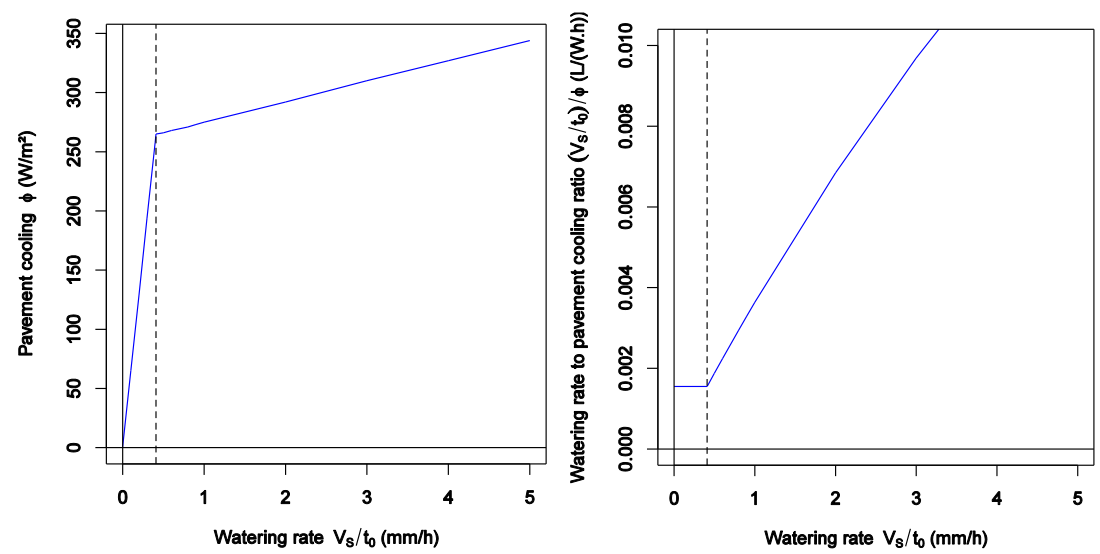

Figure 9: Pavement cooling $\Phi$ (left) and watering rate to pavement cooling ratio $\mathrm{V}_{\mathrm{S}} /\left(\Phi . \mathrm{t}_{0}\right)$ (right) according to the applied watering rate.

In regards to the optimization goals, the watering rate to pavement cooling ratio is minimized for a watering rate anywhere below the maximum evaporation rate. Therefore, any of the values below that rate are optimal. However, in order to maximize pavement-watering's cooling effect, the best watering rate is that of the maximum evaporation rate.

The authors therefore recommend adjusting the watering rate to match the maximum evaporation rate exactly. In the described experimental conditions, this would lower advective cooling to between 4 and $7 \mathrm{~W} / \mathrm{m}^{2}$, bringing total pavement cooling down to between 201 and $263 \mathrm{~W} / \mathrm{m}^{2}$, i.e. a $6-13 \%$ reduction for a $80-84 \%$ water saving.

Our estimations of latent heat flux are consistent with those reported by Météo-France and CSTB [7] who find that latent heat flux can reach $300 \mathrm{~W} / \mathrm{m}^{2}$. They also agree well with findings by He and Hoyano [5] who report an advective heat flux of 23-47 W/m and a latent heat flux of 250-320 W/m $\mathrm{m}^{2}$ for a westward-facing building wall. 
Météo-France and CSTB found an optimal watering rate of $0.2 \mathrm{~mm} / \mathrm{h}$ for all of Paris' road surfaces was found [7]. This value was obtained by testing different watering rates with a frequency of every hour and a water-holding capacity of $1 \mathrm{~mm}$. However, it is a daily and city average for watering every hour between $5 \mathrm{am}$ and $7 \mathrm{pm}$ and is not more accurately defined for individual street configurations. Furthermore, the authors were limited in the choice of the watering frequency since the model's time step was one hour and was found sufficient considering a water-holding capacity of $1 \mathrm{~mm}$. The findings reported here are therefore consistent with theirs.

Another consequence of these results is information on the water-holding capacity of the pavement. Since the pavement dries 30 minutes after watering during insolation, the waterholding capacity of the pavement is therefore equal to the amount of water evaporated in between 30-minute watering cycles, i.e. between 0.16 and $0.20 \mathrm{~mm}$. This is significantly less than that assumed by Météo-France and CSTB [7], but is only valid for the portion of pavement surveyed by the heat flux sensor. This portion has a specific geometric configuration and surface composition (cold- versus hot-mix asphalt concrete). However, it can still be asserted that the optimized watering method applies the exact water-holding capacity of the target-area at the frequency that it takes for that amount of water to completely evaporate. Thus, if it is assumed that the watering frequency used in the morning is optimal, morning evaporation can be estimated to between 0.16 and $0.20 \mathrm{~mm} / \mathrm{h}$.

Sources of uncertainty in these estimations lie in the use of $S$ rather than $R_{n}$, assumptions regarding water temperature changes and those regarding $\Delta Q$. Concerning the latter, observations over several days by Kinouchi and Kanda [2] substantiate our assumption as does the presented analysis of $G$ which is unchanged up to a constant in dry and wet conditions over the considered time span.

\section{Conclusion}

The field study conducted on rue du Louvre in Paris over the summer of 2013 has allowed us to expose the thermal effects of pavement-watering on a pavement area located $1.6 \mathrm{~m}$ away from the eastern sidewalk in a street with an aspect ratio of $\mathrm{H} / \mathrm{W}=1$ and of approximate $\mathrm{N}-\mathrm{S}$ orientation. Pavement heat flux density at $5 \mathrm{~cm}$ depth was found to be more than halved by pavement-watering during insolation. Furthermore, a heat transfer analysis based on a linear relation found between solar irradiance and heat flux density allowed the estimation of evaporative cooling to between 232 and $279 \mathrm{~W} / \mathrm{m}^{2}$, i.e. an evaporation rate of between 0.31 and $0.41 \mathrm{~mm} / \mathrm{h}$. This was confirmed by an independent estimation obtained by solving the mass convection problem. In the study conditions, evaporation was found to represent at least $85 \%$ of total pavement-watering cooling. Assuming that the one-hour morning watering cycles were optimal, the evaporation rate during morning shaded conditions is 0.16 to $0.20 \mathrm{~mm} / \mathrm{h}$. Finally, it was found that the water-holding capacity of the surveyed pavement zone is 0.16 to $0.20 \mathrm{~mm}$.

Based on these analyses, it is recommended to sprinkle the exact water-holding capacity of the pavement at the lowest possible frequency that prevents the pavement from drying. In the case described in this paper, this translates to 30-minute watering cycles with a watering rate of 0.31 to $0.41 \mathrm{~mm} / \mathrm{h}$ during pavement insolation. In the morning, 60-minute watering cycles and a watering rate of 0.16 to $0.20 \mathrm{~mm} / \mathrm{h}$ are recommended. In the experimental conditions described here, this would use at least $80 \%$ less water while still providing at least $87 \%$ of observed pavement cooling. Finally, the watering period should be extended to include a few minutes before pavement insolation begins to maximize the cooling effect. 
In order to reduce the watering frequency further and thus cause less disturbance associated with watering cycles, the pavement water-holding capacity would need to be increased. As Parisian streets are currently designed to evacuate surface water as fast as possible, a change in street design is necessary to meet this objective. One alternative that can be considered is to use water-retaining pavement materials. The new street material would have to store water at or near its surface in order not to prevent evaporation. Such a material would permit the delivery of larger amounts of water per watering cycle with lower runoff and thus reduce the watering frequency. In addition, the new road structure may be able to store rainfall from summer storms or water already being used today for street cleaning long enough for evaporation on hot days. This would lead to additional water savings all while having positive impacts on rainwater runoff management.

Water temperature, net radiation and sensible heat flux measurements as well as the determination of the thermal characteristics of the pavement material would help address the sources of uncertainty in this analysis. In addition, these measurements would help verify the conjecture on optimal watering during pavement shading via a similar approach to that used for the afternoon.

\section{References}

[1] T. Kinouchi and M. Kanda, "An Observation on the Climatic Effect of Watering on Paved Roads," J. Hydrosci. Hydraul. Eng., vol. 15, no. 1, pp. 55-64, 1997.

[2] T. Kinouchi and M. Kanda, "Cooling Effect of Watering on Paved Road and Retention in Porous Pavement," in Second Symposium on Urban Environment, 1998, pp. 255-258.

[3] R. Takahashi, A. Asakura, K. Koike, S. Himeno, and S. Fujita, "Using Snow Melting Pipes to Verify the Water Sprinkling's Effect over a Wide Area," in NOVATECH 2010, 2010, p. 10.

[4] H. Yamagata, M. Nasu, M. Yoshizawa, A. Miyamoto, and M. Minamiyama, "Heat island mitigation using water retentive pavement sprinkled with reclaimed wastewater," Water Sci. Technol. a J. Int. Assoc. Water Pollut. Res., vol. 57, no. 5, pp. 763-771, Jan. 2008.

[5] J. He and A. Hoyano, "A numerical simulation method for analyzing the thermal improvement effect of super-hydrophilic photocatalyst-coated building surfaces with water film on the urban/built environment," Energy Build., vol. 40, no. 6, pp. 968-978, Jan. 2008.

[6] J. Wei and J. He, "Numerical simulation for analyzing the thermal improving effect of evaporative cooling urban surfaces on the urban built environment," Appl. Therm. Eng., vol. 51, no. 1-2, pp. 144-154, Mar. 2013.

[7] Météo-France and CSTB, "EPICEA Project - Final Report," Paris, France (in French), 2012.

[8] M. Bouvier, A. Brunner, and F. Aimé, "Nighttime watering streets and induced effects on the surrounding refreshment in case of hot weather. The city of Paris experimentations," Tech. Sci. Méthodes, no. 12, pp. 43-55 (in French), 2013.

[9] P. Maillard, F. David, M. Dechesne, J.-B. Bailly, and E. Lesueur, "Characterization of the Urban Heat Island and evaluation of a road humidification mitigation solution in the district of La Part-Dieu, Lyon (France)," Tech. Sci. Méthodes, no. 6, pp. 23-35 (in French), 2014.

[10] A. Lemonsu, R. Kounkou-Arnaud, J. Desplat, J.-L. Salagnac, and V. Masson, "Evolution of the Parisian urban climate under a global changing climate," Clim. Change, vol. 116, no. 3-4, pp. 679-692, Jul. 2012.

[11] J.-M. Robine, S. L. K. Cheung, S. Le Roy, H. Van Oyen, C. Griffiths, J.-P. Michel, and F. R. Herrmann, "Death toll exceeded 70,000 in Europe during the summer of 2003.," C. R. Biol., vol. 331, no. 2, pp. 171-178, Feb. 2008.

[12] D. Li and E. Bou-Zeid, "Synergistic Interactions between Urban Heat Islands and Heat Waves: The Impact in Cities Is Larger than the Sum of Its Parts," J. Appl. Meteorol. Climatol., vol. 52, no. 9, pp. 2051-2064, Sep. 2013.

[13] T. Asaeda, V. T. Ca, and A. Wake, "Heat storage of pavement and its effect on the lower atmosphere," Atmos. Environ., vol. 30, no. 3, pp. 413-427, Feb. 1996. 
[14] W. Jürges, "Heat transfer on a flat wall," Beihefte zum Gesundheits-Ingenieur, vol. 19, no. 1, pp. 1227-1249 (in German), 1924.

[15] M. Santamouris, "Appropriate materials for the urban environment," in Energy and Climate in the Urban Built Environment, M. Santamouris, Ed. 2001.

[16] J. Lekner and M. C. Dorf, "Why some things are darker when wet.," Appl. Opt., vol. 27, no. 7, pp. 1278-80, Apr. 1988.

[17] H. Kusaka, H. Kondo, and Y. Kikegawa, "A simple single-layer urban canopy model for atmospheric models: comparison with multi-layer and slab models," Boundary-Layer Meteorol., vol. 101, no. 3, pp. 329-358, 2001.

[18] J. A. Duffie and W. A. Beckman, Solar Engineering of Thermal Processes, 2nd Editio. New York, 1991, p. 944.

[19] G. Pagliarini and S. Rainieri, "Dynamic thermal simulation of a glass-covered semi-outdoor space with roof evaporative cooling," Energy Build., vol. 43, no. 2-3, pp. 592-598, Feb. 2011.

[20] F. Pasquill, "The estimation of the dispersion of windborne material," Meteorol. Mag., vol. 90, no. 1063, pp. 33-49, 1961.

[21] D. Camuffo and A. Bernardi, "An observational study of heat fluxes and their relationships with net radiation," Boundary-Layer Meteorol., vol. 23, no. 3, pp. 359-368, Jul. 1982.

[22] S. J. Kline and F. A. McClintock, "Describing Uncertainties in Single-Sample Experiments," Mech. Eng., vol. 75, pp. 3-8, 1953.

[23] M. Hendel, M. Colombert, Y. Diab, and L. Royon, "Improving a pavement-watering method on the basis of pavement surface temperature measurements," Urban Clim., no. Under review.

\section{Acknowledgements}

The authors would like to thank APUR for lending their Flir TiR32 infrared camera and Orange for allowing the use of their rooftop terrace located at 46, rue du Louvre for instruments used during this experiment. They also acknowledge the support of Météo-France and APUR as well as the Green Spaces and Environment, Roads and Traffic and the Waste and Water Divisions of the City of Paris during the preparation phase of this experiment.

Funding for this experiment was provided for by the Water and Sanitation Department of the City of Paris.

\section{Nomenclature}

$\alpha \quad \alpha \quad$ conversion coefficient of solar irradiance to pavement heat flux density at $5 \mathrm{~cm} \mathrm{depth},-$

a $\quad a_{d / w}$ pavement albedo (dry/wet), -

APUR Parisian urban planning agency

$B M I_{M i n}$ Minimum biometeorological index, 3-day mean of daily low temperature, ${ }^{\circ} \mathrm{C}$

$B M I_{\text {Max }}$ Maximum biometeorological index, 3-day mean of daily high temperature, ${ }^{\circ} \mathrm{C}$

$c \quad$ water specific heat, $4.18 \mathrm{~J} / \mathrm{g} . \mathrm{K}$

$c_{p} \quad$ air specific heat, $1.005 \mathrm{~J} / \mathrm{g} . \mathrm{K}$

$\Delta Q \quad$ downwards pavement heat flux density absorbed by top 5-cm layer of pavement, $\mathrm{W} / \mathrm{m}^{2}$

$e \quad$ pavement thickness above the heat flux sensor, $5 \mathrm{~cm}$

E evaporation rate, $g / s$

$\varepsilon_{d} \quad$ dry pavement emissivity, 0.97

$\varepsilon_{w} \quad$ wet pavement emissivity, 0.98

$G$ downward conductive heat flux density, $5 \mathrm{~cm}$ below the pavement surface, $W / \mathrm{m}^{2}$

$H \quad$ upward sensible heat flux density at pavement surface, $\mathrm{W} / \mathrm{m}^{2}$

$h \quad$ convective heat transfer coefficient, $W / m^{2} . K$

$l \quad$ latent evaporation heat of water, 2,260 $\mathrm{kJ} / \mathrm{kg}$

$L_{\text {down }}$ downward longwave radiation density, $\mathrm{W} / \mathrm{m}^{2}$

$L_{u p} \quad$ upward longwave radiation density, $W / m^{2}$

$M R T$ mean radiant temperature, ${ }^{\circ} \mathrm{C}$

$p_{0} \quad$ total air pressure, $\mathrm{Pa}$

$p_{s} \quad$ saturation water vapor pressure at $T_{S}^{\text {wet }}, \mathrm{Pa}$ 
$p_{v} \quad$ partial air water vapor pressure at $T_{\text {air }}{ }^{\text {wet }}, \mathrm{Pa}$

$\Phi \quad$ total pavement cooling, $W / m^{2}$

$R_{n} \quad$ net radiation density, $W / \mathrm{m}^{2}$

$\rho \quad$ water density, $1,000 \mathrm{~kg} / \mathrm{m}^{3}$

$S$ pavement solar irradiance, $W / m^{2}$

$S$, pyranometer solar irradiance, $W / m^{2}$

$S_{\text {ref }} \quad$ reflected shortwave radiation density, $\mathrm{W} / \mathrm{m}^{2}$

$T_{\text {air }} \quad$ atmospheric air temperature, ${ }^{\circ} \mathrm{C}$

$T_{S} \quad$ pavement surface temperature, ${ }^{\circ} \mathrm{C}$

$T_{w} \quad$ water temperature, ${ }^{\circ} \mathrm{C}$

$t_{0} \quad$ watering cycle period, $h$

$V$ pavement conductive heat flux density, at surface, $\mathrm{W} / \mathrm{m}^{2}$

$V_{S} \quad$ volume of sprinkled water per watering cycle, $\mathrm{mm}$

UHI urban heat island 